\title{
Why We Won't See Any Public Universities “Going Private"
}

\author{
John D. Wiley, Ph.D.
}

Chancellor

University of Wisconsin-Madison

11 around the country the story is the same: States are reducing taxpayer
support for public higher education and offsetting those reductions with
higher tuition. Using Wisconsin as an example, Table 1 illustrates the changes over the last 25 years. In some states, the changes have been even more dramatic; in others, less so. But the trend is essentially universal. Furthermore, the impacts of these changes vary, even within one state. At UW-Madison (flagship institution of the UW System), for example, state appropriations constituted $43.1 \%$ and

tuition $10.5 \%$ of our budget in 1975 . Today, those numbers are $19.5 \%$ and $15.7 \%$ respectively. To make matters worse, nearly a third of our state revenue comes to us with constraints requiring us to return it to the state for specific costs such as our share of the state utility bills, debt service, and mandatory payments to state agencies. Even if we were able to economize or find superior alternatives in any of those areas, we would not be able to reallocate the savings for other purposes. As a result, the state is providing only $13.5 \%$ of our base operating budget-the budget for hiring faculty and staff and covering infrastructure and operating costs beyond debt service and utility bills. For the first time in the history of the institution, our students are contributing more to this portion of our operating budget than are the state taxpayers.

Viewing these trends, many faculty, alumni, newspaper editors, and even legislators have urged us to consider "going private." By that, they have in mind that we could agree to forego all state support in our base operating budget and rely on increased tuition, coupled with some unspecified amount of additional student financial aid (what they assume to be "the private model" of high tuition and high financial aid) for ongoing operations. These views are often expressed in terms of a comparison: "You're way under-priced at a resident tuition of $\$ 6000 /$ year. I'm

Draft version of a chapter in What's Happening to Higher Education?, Ronald G. Ehrenberg editor, copyright 2006. Reproduced with permission of Greenwood Publishing Group, Inc., Westport, CT 


\begin{tabular}{|l|r|r|}
\hline & $1974-75$ & $2004-05$ \\
\hline State appropriations for UW-System per \$1000 of personal income & $\$ 12.50$ & $\$ 5.50$ \\
\hline $\begin{array}{l}\text { State appropriations for UW-System as a share } \\
\text { of total state spending }\end{array}$ & $11.5 \%$ & $3.9 \%$ \\
\hline State appropriations for UW-System per FTE student (2004 dollars) & $\$ 10,600$ & $\$ 7,400$ \\
\hline $\begin{array}{l}\text { State appropriations for UW-System as a percent of UW-System } \\
\text { budget }\end{array}$ & $49.5 \%$ & $26 \%$ \\
\hline Tuition as a percent of UW-System budget & $12 \%$ & $21 \%$ \\
\hline
\end{tabular}

Table 1. Illustrations of the changing mix of state funding and tuition in the University of Wisconsin System over the last 25 years. ${ }^{1}$

paying three times that for my daughter's tuition at [a private school], and the education she's getting is certainly not three times better. Even if you simply doubled your tuition, you would still be a bargain, and you could replace nearly all state funds. What's the problem?" Quite aside from political considerations (unwillingness of states to "let go" of prior investments and ongoing oversight), the larger problem is that the "private model," properly understood, simply cannot be scaled up to the extent required. It's a matter of simple arithmetic, and the numbers just don't work! Before explaining this assertion, it is important to review the overall context and scope of American higher education at the start of the 21st century.

At the beginning of the 20th century, formal education was a relative rarity. Many did not complete what would today be called elementary school, and it wasn't until about 1940 that the percentage of adults over age 25 who had completed high school exceeded $25 \%$. By 1940, the percentage of adults over age 25 who had completed college was still less than 5\%. Today, nearly $90 \%$ of adults over 25 have high school diplomas, and nearly 30\% have college degrees. ${ }^{2}$ The great expansion of formal education at all levels, and especially the growth of college attendance, occurred during a 30 year period after the end of WWII, spurred in great part by the GI Bill. It is fair to say that the GI Bill and the dramatic expansion of postsecondary education powered the U.S. economy for the entire second half of the 20th century.

Although the growth rate slowed in about 1975, both high school and college graduation attainment rates have continued to increase to the present date. What has made this dramatic growth possible is the conscious, thoughtful, well-planned expansion of public higher education. By and large, it is these new and expanded institutions, subsidized by the state taxpayers, which have provided the increased access to affordable higher education as a matter of public policy.

Table 2 summarizes the current system of higher education in the United States. Our present system consists of a large number of small private institutions and a smaller number of much larger public institutions. Public schools constitute only $41 \%$ of the total, 


\begin{tabular}{|l|c|c|c|}
\hline Institution Type & Public & Private & \% Public \\
\hline Number of 4-year institutions & 631 & 1835 & $25.6 \%$ \\
Enrollments & $6,236,455$ & $3,440,953$ & $64.4 \%$ \\
Average enrollment & 9,883 & 1,875 & - \\
\hline Number of 2-year institutions & 1,081 & 621 & $63.5 \%$ \\
Enrollments & $5,996,701$ & 253,878 & $95.9 \%$ \\
Average enrollment & 5,547 & 409 & - \\
\hline Total \# of institutions & 1,721 & 2,456 & $41.1 \%$ \\
Total enrollments & $12,233,156$ & $3,694,831$ & $76.8 \%$ \\
\hline Total expenditures & $\$ 170,344,841,000$ & $\$ 85,048,123,000$ & $66.7 \%$ \\
Average expenditure/student & $\$ 13,924.85$ & $\$ 23,018.14$ & - \\
\hline
\end{tabular}

Table 2. Statistical overview of the U.S. system of higher education. ${ }^{3}$

but they enroll $77 \%$ of the students, and educate them at about half the cost per student. Economies of scale are even more striking if you isolate the four-year institutions: Here, only $25 \%$ of the institutions enroll $65 \%$ of the students. Of the 100 largest post-secondary institutions in the country, 92 are public; and all of the 25 largest institutions are public, including most of the public flagship institutions of the upper Midwest (the "Big Ten" schools).

There are good and simple reasons why there are so few large private colleges and universities, and the reasons have entirely to do with base budget realities. The operational incomes of all colleges and universities derive from only a few sources:

1. Federal revenues - primarily research funds and student financial aid;

2. Program revenues* - from sales of things like athletic tickets, dormitory

*Depending on the details of the agreement, nonfederal research grants and contracts are typically accounted for in one or the other of these categories. space, food, books, hospital revenues, fees for continuing adult education, contract research, etc.;

3. Gifts and endowment income ${ }^{*}-$ annual gifts that can be expended immediately, as well as annual earnings on long-term endowments;

4. Tuition-actual revenue received from students and their families, exclusive of institutional assistance; and

5. State support-state appropriations paid directly to the institutions.

The first two categories-federal and program revenues-are not available to support the general operations of the institution. It is not possible, for example, to accept a federal grant for research in geology, and then reallocate those funds to hire a new Spanish instructor. Similarly, no President can sell tickets to a football game and then cancel the game, using the proceeds instead to add new sections of calculus. Many gifts are similarly restricted, but it is possible, over a period of many years, to build endow- 


\begin{tabular}{|l|c|c|}
\hline \multicolumn{1}{|c|}{ Funding category } & $\begin{array}{c}\text { Public 4-year } \\
\text { Institution }\end{array}$ & $\begin{array}{c}\text { Private 4-year } \\
\text { Institution }\end{array}$ \\
\hline Endowment income & $0.9 \%$ & $31.5 \%$ \\
\hline State appropriation & $30.9 \%$ & $0.3 \%$ \\
\hline Tuition income & $18.1 \%$ & $24.4 \%$ \\
\hline
\end{tabular}

Table 3. Percentage of total institutional operating budgets from the three major categories of base-budget sources for public and private 4-year institutions. ${ }^{3}$

ments that can support faculty salaries, program operations, and other "basebudget" needs. Thus, the base operating budgets of private and public universities are made up entirely of the same three kinds of revenue: gifts and endowment income, tuition, and state support. Table 3 shows how these three revenue categories contribute to the budgets of public and private colleges and universities.

It's no surprise that private schools derive so little of their revenues from state governments, nor that public schools have so little endowment income. What most people do find surprising is that the contribution of tuition revenues is so similar between public and private institutions. After all, the average tuition at private schools is $\$ 16,287 /$ year, and the average tuition at public schools is only $\$ 3,746 /$ year. ${ }^{3}$ So why isn't this large difference reflected in the budget percentages? The answer is found mostly in the gross revenue numbers. The 3,308,460 students enrolled in private colleges and universities generated $\$ 29,257,523,000$ in tuition and fees, ${ }^{3}$ for an average of $\$ 8844$ per student, which is only about half the theoretical or "sticker-price" amount. This reflects the substantial tuition discounting that is necessary for institutions having very high stickerprice tuition.

In contrast, the 6,055,398 students enrolled in public institutions generated $\$ 23,376,317,0003$ for an average of $\$ 3681 /$ student-pretty close to the average advertised tuition of $\$ 3746$.

Therein lies the first lesson for those urging public universities to "go private:" If public universities raised their tuition to private school levels, they would not realize anything like the apparent theoretical increase in tuition revenue, because they would find it necessary to engage in the same tuition discounting as the private institutions. After all, a student or family that is unwilling or unable to pay the stickerprice tuition at private schools is hardly likely to be willing or able to do so at public schools!

The second important point should be obvious from Table 3: As a percentage of their overall budgets, private schools realize as much revenue from gift and endowment income as public schools obtain from state subsidies. Put differently, public funds at public schools play the same role as gift and endowment income at private schools. Thus, even if public schools 
were able to raise their tuition to private school levels, they would still need substantially increased private giving and endowment income to offset any loss of public funding.

The percentages in Table 3 are based on averages over hundreds of institutions, and do not apply to any one institution. To illustrate the challenge of moving a specific institution from the public to the private model, I will use the University of Wisconsin-Madison as a concrete example. In 2004, our total budget of $\$ 1.9$ billion included $\$ 369.7$ million in state appropriations, \$297 million in tuition, and about $\$ 120$ million in endowment income and the equivalent in annual gifts. Thus, the budget percentages for these categories were $19.5 \%, 15.7 \%$, and about $6.3 \%$ respectively. In round numbers, our undergraduate tuition for nonresidents is $\$ 19,000$, and for residents is $\$ 6,000$. Actually, we have lots of different tuitions at various degree levels, but setting all tuitions at the nonresident undergraduate level of $\$ 19,000$ is a reasonable proxy for taking the first step toward the "private model."

If all tuitions were set at $\$ 19,000$, our roughly 40,000 students would theoretically generate $\$ 70$ million/year. Assuming we were forced to do the same level of tuition discounting as the private institutions, however, we would yield only $54.3 \%$ of that amount, or about $\$ 413$ million - an increase of $\$ 116$ million over current tuition revenues. But if we are to give up all state support, we will still be short $\$ 369.7-\$ 116=\$ 253.7$ million. The only feasible source for making up that difference is charitable gifts and endowment income. As a rule of thumb, endowments generate only about $4-5 \%$ of the principal as expendable income annually. Any earnings in excess of that are typically reinvested to allow the endowment to grow as a compensation for inflation. In order to generate an additional \$253.7 million in endowment income, we would need to increase our endowment by at least $\$ 5$ billion, to a total of about $\$ 7$ billion. More realistically, we would need at least $\$ 8$ billion, with most of the new endowment money being unrestricted or restricted for things such as faculty salaries and fringe benefits (endowed chairs).

There are several ways to put a hypothetical UW-Madison endowment of $\$ 8$ billion in perspective:

1. Currently, only five of the nation's 4,168 colleges and universities have endow-ments that large (Stanford, $\$ 8.6$ billion; the entire University of Texas System, $\$ 8.7$ billion; Princeton, $\$ 8.7$ billion; Yale, $\$ 11$ billion; and Harvard, \$19 billion) and all of these except the UT System are much smaller institutions than UWMadison. The UT System is, of course, still public and still receives state support.

2. In the 60-year history of the UWFoundation (our charitable fundraising foundation), we have raised a total of about $\$ 3$ billion, including net income and gains on prior investments, and approximately $\$ 1$ billion of that remains today as a permanent endowment. In addition, we have access to another $\$ 1$ billion or so in high restricted endowments, for a total of around $\$ 2$ billion. By the time we raised an additional $\$ 6$ 
billion, it would no longer be sufficient because of ongoing inflation.

3. We are currently in a six-year campaign to raise $\$ 1.5$ billion, and we will succeed in doing that. But a substantial fraction of that total will be restricted for things that have nothing to do with our base operating budget. The thirty bestendowed private universities have per-student endowments in the $\$ 500,000 /$ student range, while the best endowed public universities are endowed in the $\$ 40,000 /$ student range. ${ }^{3}$ Even at an endowment of $\$ 8$ billion, UW-Madison would still have only $\$ 200,000 /$ student-less than half the endowment resources per student of peer private institutions unless we downsized to a student body of perhaps 15-20,000 students, so my estimate of a required $\$ 8$ billion endowment is very conservative for a school our size. My conclusion is that UWMadison has essentially no chance of raising an endowment large enough to offset a total loss of state funding. I don't believe any other state flagship institution could do it, either, and most of the smaller public institutions have no present endowments at all, nor any significant fundraising potential.

On a national scale, it would require endowments totaling about $\$ 1.3$ trillion to generate enough endowment income to replace all state funding of higher education. That is about six times larger than the total of all public and private university endowments today. It is also a nontrivial fraction of the $\$ 37$ trillion total financial assets of all U.S. households, ${ }^{4}$ especially when you consider that much of the $\$ 37$ trillion is tied up in home equity. Nevertheless, the financial resources do exist, in principle, to create an aggregate "trilliondollar-plus" higher education endowment from private gifts. In 2002, private philanthropy in the U.S. totaled $\$ 240.9$ billion, of which $\$ 183.7$ billion was from gifts by individuals. ${ }^{5}$ Of the total giving, $\$ 84.3$ billion (35\%) went to religious organizations, $\$ 37.6$ billion $(16 \%)$ to health and human service causes, and $\$ 31.6$ billion (13\%) to education at all levels. There is no reason to believe the patterns or magnitudes of charitable giving can or will change quickly, so from every perspective I can think of, this is a fool's pursuit. Furthermore, it is a pursuit that has not been launched by any form of reasoned public policy debate.

I know of no legislature or other public forum that has concluded and recommended that this massive shift in the finances of higher education from the public to the private sector is good public policy for any state or for the nation. Rather, the shift is occurring incrementally in small, expedient budget decisions that manage to get the states through one more budget year. In effect, the message is this: Instead of supporting public higher education by taxing all 285 million citizens about \$220 annually each, let's ask 10 percent of them voluntarily to provide $\$ 2,200$ a year; or 1 percent of them to pony up $\$ 22,000$ a year. If there are 285 billionaires out there who would be willing to contribute $\$ 220$ million/year to save everyone else a $\$ 220$ tax bill, they 


\begin{tabular}{|l|c|c|c|c|}
\hline \multicolumn{1}{|c|}{ Highest Degree } & $\begin{array}{c}\text { Mean } \\
\text { Earnings }\end{array}$ & $\begin{array}{c}\text { Years in } \\
\text { School }\end{array}$ & $\begin{array}{c}\text { Years } \\
\text { Working }\end{array}$ & $\begin{array}{c}\text { Lifetime } \\
\text { Earnings }\end{array}$ \\
\hline No HS Diploma & $\$ 18,826$ & 11 & 50 & $\$ 941,300$ \\
HS Diploma & $\$ 27,280$ & 13 & 48 & $\$ 1,309,440$ \\
Some College & $\$ 29,725$ & 14 & 47 & $\$ 1,397,075$ \\
Associate Degree & $\$ 34,177$ & 15 & 46 & $\$ 1,572,142$ \\
Bachelors Degree & $\$ 51,194$ & 17 & 44 & $\$ 2,252,536$ \\
Masters Degree & $\$ 60,445$ & 19 & 42 & $\$ 2,538,690$ \\
Doctoral Degree & $\$ 89,735$ & 22 & 39 & $\$ 3,499,626$ \\
Professional Degree & $\$ 112,845$ & 22 & 39 & $\$ 4,400,955$ \\
\end{tabular}

Table 4. Mean earnings and expected mean lifetime earnings in constant 2002 dollars by degree of educational attainment, assuming retirement at age 65.5

haven't stepped forward to do so. In the meantime, states continue to push their public colleges and universities toward this ultimately impossible goal.

This stark budget reality of our public universities is already diminishing the health of the U.S. system of higher education, and it is something in which every citizen has a huge stake. Access and affordability are not just issues for a few potential students and their families: These are issues on which the entire economy will either thrive or decline. Simple arithmetic confirms it. Today, the public invests a little more than $\$ 392$ billion annually-nearly $\$ 1400$ per capita, or about $\$ 8,000$ per pupil-to provide universal, tuition-free education through grade 12 . Multiplying $\$ 8,000$ times 13 years of K-12 education shows that we taxpayers invest about $\$ 100,000$ to produce a high school graduate. A glance at Table 4 shows that the average person who enters the workforce with only a high school education is unlikely ever to repay in state and local taxes the cost of his or her diploma. It is only at the bachelors degree level and above that the public can expect to regain their investment in $\mathrm{K}-12$ education from tax revenues. Let me quickly add that many high-school graduates obtain apprenticeship training or other skills that enable them to beat these odds. Similarly, some college graduates will fall far short of the earnings detailed in Table 4. Still, the overall economy consists of the accumulation of those averages, so the above conclusions are important for the economy as a whole.

In the middle of the last century, taxpayers and lawmakers alike seemed to understand this simple math. They wisely invested in a massive expansion of public higher education, and provided affordable access to millions of citizens through the GI bill, low tuition, and abundant scholarship support to those who needed it. Those decisions created the engine that powered the state and national economies for the entire second half of the 20th century. The vast majority of you who are 
reading this article benefited personally from that affordable access, as did society at large. Why, then, would we even consider withdrawing it from our children and their children? But that's just what we're doing. Federal scholarships have all but disappeared, replaced by loans. More than three quarters of students now work for paying during the school year when they should be studying - and they are working more hours every year. More than half of all UW-Madison graduates now graduate with student loan debts ranging, on average, from $\$ 15,000$ at the bachelors level to more than $\$ 100,000$ for veterinary, law, and medical school. The prospect of starting a career with large debt is now driving students away from careers that have only "average" lifetime earning potential, including teaching, nursing, family practice medicine, rural medical or law practice, and large animal veterinary practice. Even more importantly, the distribution of brains, talents, ambition, and creativity is independent of family income. We will ignore that fact and freeze out the children of average and low-income families at our great peril. No society is rich enough to waste any of these assets.
When setting out on a path that leads toward an impossible goal, only one thing is certain: you won't get there. There is no realistic possibility of providing high-quality postsecondary education for the vast majority of our high school graduates with a purely private financing model. It isn't clear how we will get off this path, but the longer we stay on it the greater the cost in lost talent, lost opportunities, and economic stagnation. What we need is a serious public policy discussion setting out the public as well as private benefits of having a highly educated workforce, and deciding what fraction of the costs of education should be borne by the recipients of that education and what fraction borne by the public at large for the benefits they receive. Continuing to drive blindly in the direction of privatization is a path to ruin.

1. Data pertaining to the UW-System and UWMadison are from the UW-Madison Office of Budget Planning and Analysis.

2. National Center for Education Statistics, Digest of Education Statistics, 2003.

3. Chronicle Almanac 2003-04, Chronicle of Higher Education, August 29, 2003.

4. New York Times, May 22, 2005.

5. U.S. Census Bureau, Statistical Abstract of the United States: 2004-05 (124th Edition)

Washington, D. C. 2004. 


\section{A Concrete Personal Example John D. Wiley}

In 1960, when I graduated from high school in Evansville, Indiana, my father (a hospital pharmacist) was earning about $\$ 10,000$ per year, which provided total or partial support for himself, my mother, five children, and a grandmother. Without even considering private schools, I applied to Indiana University - my state university. The tuition for my freshman year was \$125, and the total cost of attendance, including room, board, books, and other expenses was about $\$ 1000$ per year. Through newspaper-route savings and summer jobs, I managed to pay for about one full year of the costs. Scholarships provided the equivalent of another year, and my family paid for the remaining two years. As a result, I graduated in four years totally debt-free. During my senior year, I was joined at IU by one of my sisters. What my parents could foresee for the next fifteen years was that they would always have at least one of us in college, and sometimes up to three at once. Nevertheless, it looked manageable with good planning. Tuition was only $1.25 \%$ of their gross income.

Using the consumer price index to inflate a 1960 salary of $\$ 10,000$ to today's dollars, results in a 2005 salary of about \$65,000; this is $44 \%$ above today's median family income of $\$ 45,000$. The 2005 resident undergraduate tuition at UW-Madison was about \$6,000, or $9.2 \%$ of $\$ 65,000$ and $13 \%$ of $\$ 45,000$. In 2005, my family would have needed an annual income of $\$ 480,000$ to be in a position comparable to their reality of 1960 . Only $1.3 \%$ of households have incomes above $\$ 250,000 / y e a r$, so there is no doubt that public higher education has become dramatically less affordable for nearly everyone. 